\title{
Disease Prevalence of Indian Major Carps in Semi Intensive Culture System
}

\author{
J. Yaswanth Kumar ${ }^{1 *}$, S. Janardana Reddy ${ }^{1}$ and T. Suguna ${ }^{2}$ \\ ${ }^{1}$ Department of Fishery Science and Aquaculture, SVU College of Sciences, Sri Venkateswara \\ University, Tirupati, Andhra Pradesh, India \\ ${ }^{2}$ Fisheries Research Station, Sri Venkateswara Veterinary University, Undi, West Godavari \\ (dist), Andhra Pradesh, India \\ *Corresponding author
}

\section{A B S T R A C T}

\section{Keywords}

Diseases, Indian major carps, Bacterial, Parasitic and West Godavari \& Krishna districts of Andhra Pradesh

\section{Article Info}

Accepted:

07 March 2020

Available Online:

10 April 2020
In recent years, there is a significant expansion in commercial pond carp culture in India. While much of this development has focused on Andhra Pradesh, Punjab and Haryana, there are several other states such as Orissa, Karnataka and Tamil Nadu where commercial carp culture is gaining momentum. Diseases of varied etiology are, however, a serious constraint to the success of many of the freshwater culture systems. With the intensification of culture, fish health problems have become very common in Andhra Pradesh carp culture systems. There are several aquatic animal health problems in different culture systems that influence production from such systems. Infectious diseases of cultured freshwater carps are one of the major problems to successful aquaculture industry. Several bacterial, parasitic and fungal diseases have been documented in freshwater culture systems of Andhra Pradesh. The present work was conducted to isolate and identify different diseases from Indian Major Carps. Diseases pose a severe risk for sustainability of aquaculture. They cause physical and economic losses. As aquaculture is intensifying and diversifying, vulnerability to diseases is increasing accordingly. The epidemic spread and devastating effects of aquatic animal diseases such as bacterial, parasitic \& fungal diseases have been documented in fresh water culture systems especially the carp culture system of Kolleru area of Andhra Pradesh. The present work is prioritised in the selected two districts i.e. West Godavari \& Krishna (Kolleru area) of Andhra Pradesh, to isolate \& identify the incidence of various pathogens of diseases seasonally in Indian major carp's species.

\section{Introduction}

Aquaculture plays an important role in the livelihood of people and in the national economy of countries in Asia. It produces food fish, which is an important component of the diet of the people; it provides income and employment opportunities for many coastal and rural people; and it help to earn foreign exchange. India has a total of $8118 \mathrm{kms}$ of coastline and 2.02 million sq.kms of EEZ. Aquaculture in India has witnessed an 
impressive transformation from a highly traditional activity to a well developed and diversified industrial activity. In an aquatic environment, there is a profound and inverse relationship between environmental quality and disease status of fish. Health maintenance is a positive concept that will result in more efficient production, rather than mere prevention of disease. The goal of health maintenance is to improve the health and wellbeing of animals that appear to be generally healthy.

Diseases are one of the most serious limiting factors in aquaculture. High density favours the spread of many diseases and parasites. The frequency and severity of disease outbreaks have increased with increased aquaculture activity. In recent years, there have been concerted efforts made for better understanding of piscine immune system and its relation to protection against infectious disease agents. The late eighties witnessed a drastic technological transition in the aquaculture industry from traditional to semi intensive and more sophisticated intensive farming systems. These were more capital intensive and required more managerial and technological inputs. Here the stocking density was kept at very high level and water quality was maintained with different aeration systems and frequent water exchanges. The organisms were completely dependent on the artificial feeds formulated exclusively to meet their nutritional requirements.

The overcrowding and deterioration of the excess feed and waste caused tremendous stress to the cultured organisms leading to the immunosuppression and the outbreaks of different diseases. The high amount of economic risks associated with the disease outbreaks attracted more attention to disease diagnosis and preventive measures. The traditional methods of isolation and identification of the pathogenic organisms were of not much important in the aquatic medium as the therapeutics were not specific and less cost effective.

The studies on fish diseases in our country are limited. It is indeed important to acquire knowledge on different pathogens, their biology and life cycle to recognize the fish diseases. The links of interrelationship between fish and environment is important to understand the defects or deficiencies to resist fish from pathogens. Our less understanding of their physiological characterized particularly by their poikiloothermy hinders the study of the diseases of fish, contrast with much understood physiology of homeothermic animals.

Diagnosis of fish diseases is classified as epidemiological, clinical, postmortem examination, microbiological and histopathological methods. At this time, far too little is known about the interrelationships of the casual environmental and physiological factors in the fish disease process. Application of epidemiological concept to diseases in human and veterinary medicine have proved to be a very reliable and powerful tools in containing and even eradicating diseases in human and animals. This in itself should be sufficient cause to explore their applicability to fish health management as well as to fish disease diagnosis.

\section{Materials and Methods}

The semi-intensive carp culture system, popularly known as 'Kolleru carp culture', operates at production levels of between 7 000 to $10000 \mathrm{~kg} / \mathrm{ha} / \mathrm{annum}$. In the Kolleru region, an estimated 700000 tonnes of carp is produced per annum. The pond systems are based on two culture species, viz. rohu and catla. These species are stocked at ratios of 80 to 90: 10 to 20 (rohu: catla) with the occasional addition of mrigal. Prevalence of disease infestation in fresh water carps was carried out for a period of 10 months between 
June, 2016 to March, 2017 in two districts of Andhra Pradesh namely Krishna, and West Godavari in one or several blocks known to have adequate fisheries resources. Around 75 fish farms of size ranging from 3 to 50 acres were randomly selected. The fishes were brought to the laboratory in live condition with water filled buckets and the total length, body weight of fishes was taken. The date and site of collection were recorded and the fishes were examined for diseases. External symptoms and health conditions of each specimen were recorded.

\section{Determination of disease frequency Index}

The disease frequency Index was calculated by taking the percentage of the number of hosts infected by individual diseases against the total number of hosts examined in a particular area under investigation.

Prevalence $(\%)=$ Total number of infected fishes/total number fish hosts examined $\mathrm{X}$ 100

\section{Statistical analysis}

Two way anova was done to determine the significance of differences in disease frequency index of diseases among different seasons as well as different months.

\section{Results and Discussion}

Disease is one of the major constrains to aquaculture and limiting factor for economic and socio-economic development in India and as in many other countries of the world. Some diseases have caused serious damage, not only the livelihood of fish farmers, but also, to the future development of the industry. Many diseases affecting present day aquaculture is resultant of intensification of culture practices without the basic perception of intricate balance between host, pathogen and environment. Monthly incidence of different diseases in Indian major carps depicted in Table 1 and Figure 1.

\section{Monthly Prevalence (\%) of bacterial diseases and occurrence of diseases in different seasons}

Bacterial diseases i.e. red disease and columnaris disease are observed during entire study period. During the study period infestation of red disease highest in the month of January (100\%), December (98.75\%) followed by February, October; lowest in the month of July (72.41\%) (Table 2). Skin lesions are often noticed at base of the fins, with variously sized areas of haemorrhage necrosis. There are red areas on body, skin ulcers, swollen body abdomen and eyes and musculature hence often called as red disease. The incidence of columnaris disease observed in the month of July (55.10\%), followed by June (25.0\%), August (24.13\%) and lowest prevalence of columnaris disease in the month of March (4.16\%), November (8.69\%). Another significant observation in aquaculture has been seasonal variation in occurrence and severity of fish disease in fresh water aquaculture. The incidence of red diseases is highest in monsoon winter season (97.05\%), but occurrence of red disease is common during all seasons. The incidence of columnaris disease is highest in rainy season $(32.94 \%)$ followed by monsoon winter $(17.64 \%)$.

Bacterial fish diseases are very common and are one of the most difficult health problems to deal with. These bacteria are generally saprophytic in nature and only become pathogenic when fishes are physiologically unbalanced, nutritionally deficient, or there are other stressors, i.e., poor water quality, overstocking, which allow opportunistic bacterial infections to proceed. Bacterial diseases have been frequently encountered in 
eggs, fry, fingerlings of fish, causing heavy mortality. These microorganisms are essentially opportunistic pathogens which invade the tissues of a fish host rendered susceptible to infection by stress factors.

Mishra et al., (2017) stated that occurrence of columnaris bacterial disease that affects the skin or gills of fresh water fish and is caused most commonly by flexibacter columnaris. This is primarily on epithelial disease and necrosis and erosions of the skin and gills are often observed which may become systemic.

\section{Monthly prevalence (PFI \%) of parasites in Indian major carps}

Highest parasitic frequency index (PFI) was observed in months of June $(75.0 \%)$, July $(65.50 \%)$ and lowest in the month of September (1.33\%). Occurrences of parasitic fauna such as Dactylogyrus sp, ParaDactylogyrus, Myxobolous sp, Argulus $\mathrm{sp}$, were reported from Indian major carps in our present study. Parasitic frequency Index of Dactylogyrus sp was found in highest in July $(55.17 \%)$ and lowest prevalence was found in September (13.33\%).

Parasitic frequency index (PFI) of Myxobolous sp were found highest in June and myxobolous was not found in the months of September, October, January, February during 10 months period. The results supported by Das et al., (1989), Narasimhamurthi and Kalavati (1984) and Basu and Haldar (2003) who have recorded high prevalence of myxozoan parasites during August to January and lowest prevalence in the month of February.

Prevalence of Argulus was found in June, July, October and January; ' 0 ' \% prevalence was observed in August, September, November, December, February, March. Occurrence of parasitic fauna due to high stocking density, water depth, temperature along with other physio chemical parameters and management practices maintained in culture systems.

Table.1 Monthly incidence of different diseases in Indian major carps

\begin{tabular}{|l|l|l|l|l|l|l|l|}
\hline S. No & $\begin{array}{l}\text { Month of } \\
\text { Sampling }\end{array}$ & $\begin{array}{l}\text { No. of diseased } \\
\text { samples } \\
\text { collected from } \\
\text { farmers }\end{array}$ & $\begin{array}{l}\text { Red } \\
\text { disease }\end{array}$ & Flukes & $\begin{array}{l}\text { Incidence of disease } \\
\text { Columnaris } \\
\text { disease }\end{array}$ & Myxobolous & Argulus \\
\hline $\mathbf{1}$ & June, 2016 & 24 & 20 & 12 & 6 & 4 & 2 \\
\hline $\mathbf{2}$ & July,2016 & 58 & 42 & 32 & 32 & 2 & 4 \\
\hline $\mathbf{3}$ & August, 2016 & 58 & 54 & 20 & 14 & 2 & - \\
\hline $\mathbf{4}$ & September, 2016 & 30 & 26 & 4 & 4 & - & \\
\hline $\mathbf{5}$ & October, 2016 & 42 & 40 & 6 & 8 & - & 2 \\
\hline $\mathbf{6}$ & November, 2016 & 46 & 42 & 12 & 4 & 4 & - \\
\hline $\mathbf{7}$ & December, 2016 & 80 & 79 & 36 & 16 & 10 & - \\
\hline $\mathbf{8}$ & January, 2017 & 70 & 70 & 34 & 14 & - & 4 \\
\hline $\mathbf{9}$ & February, 2017 & 76 & 74 & 30 & 12 & - & - \\
\hline $\mathbf{1 0}$ & March, 2017 & 48 & 42 & 20 & 2 & 2 & - \\
\hline
\end{tabular}


Table.2 Monthly prevalence of diseases in Indian major carps during June, 2016- March, 2017

\begin{tabular}{|c|c|c|c|c|c|c|c|c|c|c|}
\hline \multirow[t]{2}{*}{ Diseases } & \multicolumn{10}{|c|}{ Prevalence (\%) of bacterial diseases } \\
\hline & June & July & August & September & October & November & December & January & February & March \\
\hline Red disease & 83.33 & 72.41 & 93.10 & 86.66 & 95.23 & 91.30 & 98.75 & 100 & 97.36 & 87.50 \\
\hline $\begin{array}{l}\text { Columnaris } \\
\text { disease }\end{array}$ & 25.00 & 55.10 & 24.13 & 13.33 & 19.04 & 8.69 & 20.0 & 20.0 & 15.78 & 4.16 \\
\hline Parasites & \multicolumn{10}{|c|}{ Prevalence (\%) of Parasitic diseases } \\
\hline Dactylogyrus & 50.00 & 55.17 & 34.48 & 13.33 & 14.28 & 26.08 & 45.00 & 48.57 & 39.47 & 41.66 \\
\hline Myxobolous & 16.66 & 3.44 & 3.44 & 0 & 0 & 8.69 & 12.50 & 0 & 0 & 4.16 \\
\hline Argulus & 8.33 & 6.89 & 0 & 0 & 4.76 & 0 & 0 & 5.71 & 0 & 0 \\
\hline $\begin{array}{l}\text { Parasitic } \\
\text { frequency } \\
\text { Index }(\%)\end{array}$ & 75.00 & 65.50 & 37.90 & 1.33 & 19.04 & 34.78 & 57.50 & 54.30 & 39.47 & 45.80 \\
\hline
\end{tabular}

Table.3 Prevalence of disease in Indian major carps in different seasons (June, 2016-March, 2017)

\begin{tabular}{|c|c|c|c|c|c|c|}
\hline Season & $\begin{array}{c}\text { Number } \\
\text { of samples } \\
\text { collected }\end{array}$ & $\begin{array}{c}\text { Red } \\
\text { disease } \\
(\%)\end{array}$ & $\begin{array}{c}\text { Columnaris } \\
(\%)\end{array}$ & $\begin{array}{c}\text { Flukes } \\
(\%)\end{array}$ & $\begin{array}{c}\text { Myxobolous } \\
(\%)\end{array}$ & $\begin{array}{c}\text { Argulus } \\
(\%)\end{array}$ \\
\hline $\begin{array}{l}\text { Rainy season } \\
\text { (June - September) }\end{array}$ & 170 & $\begin{array}{c}142 \\
(83.52)\end{array}$ & $\begin{array}{c}56 \\
(32.94)\end{array}$ & $\begin{array}{c}68 \\
(40.00)\end{array}$ & $\begin{array}{c}8 \\
(4.70)\end{array}$ & $\begin{array}{c}6 \\
(3.52)\end{array}$ \\
\hline $\begin{array}{l}\text { Monsoon winter } \\
\text { (October - January) }\end{array}$ & 238 & $\begin{array}{c}231 \\
(97.05)\end{array}$ & $\begin{array}{c}42 \\
(17.64)\end{array}$ & $\begin{array}{c}88 \\
(36.97)\end{array}$ & $\begin{array}{c}14 \\
(5.88)\end{array}$ & $\begin{array}{c}6 \\
(2.52)\end{array}$ \\
\hline $\begin{array}{l}\text { Spring } \\
\text { (February - March) }\end{array}$ & 124 & $\begin{array}{c}116 \\
(93.54)\end{array}$ & $\begin{array}{c}14 \\
(11.29)\end{array}$ & $\begin{array}{c}50 \\
(40.32)\end{array}$ & $\begin{array}{c}2 \\
(1.61)\end{array}$ & 0 \\
\hline
\end{tabular}

Fig 1.Monthly incidence of different diseases in Indian major carps

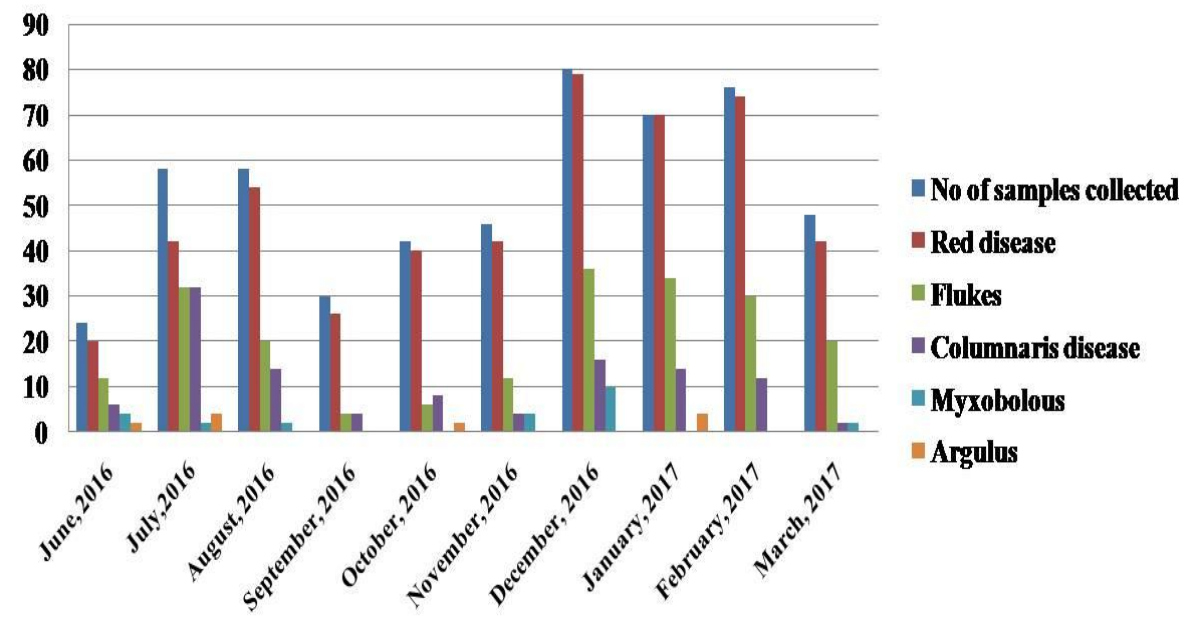


Fig 2. Prevalence (\%) of disease in Indian major carps in different seasons

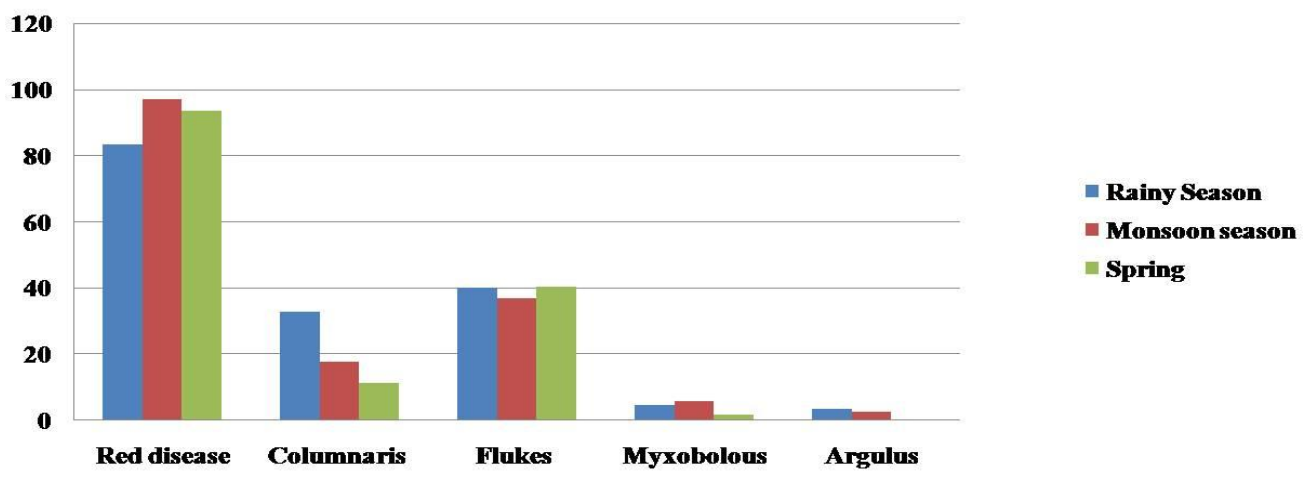

Occurrence of parasites in different was not recorded. seasons

The total study period was divided in to three season's i.e. rainy season (June -September) monsoon winter (October- January) and spring (February-March). Prevalence of disease in Indian major carps in different seasons depicted in Table 3 and Figure 2.

Dactylogyrus, paraDactylogyrus sps (flukes) were found in all seasons and highest in spring and rainy season and lowest in monsoon winter. In the present study monogeneans were observed mainly in the gills and skin of the host. The PFI of Dactylogyrus sp was highest in the month of July (PFI, 55.17\%) and lowest in October (PFI, 14.28\%).

Argulus sps were found mainly in the rainy season (PFI, 2.52\%) and monsoon winter (PFI, 2.52\%) stated as rare and not found in the spring season. Lernea sps were rarely found in different seasons. When the carps are loose their appetite results stress condition and get affected by different diseases at that time. Argulus sps were only found in June, July, October and January which is considered as rare and rest of the months it

During the study period the infestation of myxobolous $\mathrm{sp}$ highest during monsoon winter (PFI, 5.88\%) and lowest during spring (PFI, 1.61\%). The significant fluctuations in the prevalence of parasites are due to the seasonal interference with the ecology and physiology of the fish (Ahmed et al 1991; Wisheiwski, 1958). The Prevalence of parasites reported highest in June, July and December; lowest prevalence of parasites reported in month of September (1.33\%). Present study was supported by the work of Farhaduzzaman et al., (2010), the highest number of parasites reported in December and lowest in February. The parasitic infestation is greatly influenced by the season, which basically interferes with ecology and physiology of the fish.

Among bacterial, parasitic diseases occurrence of red, columnaris diseases, Gill fluke, myxobolous, Argulus are more during monsoon winter than spring \& rainy season and hence the farmers are advised to take due preventive and control measures during post rain and winter seasons in grow out culture system. 
In conclusion development of suitable preventive and control measures, specifically therapy for fish diseases assumes paramount significance, for the farmers to protect their crop against pathogens. Besides implementation of better management practices (BMP) is important to prevent frequent occurrence of disease and production loss in aquaculture. Further enhancement in knowledge about the disease process, host pathogen and the environment interaction leading to disease occurrence, are very much essential for development of scientific methods of disease control programme.

\section{References}

Ahmed, A., Ali, S. M. K and Samad, A. 1991. Probable cause of fish ulcer in Bangladesh, Nutrition news, 14 (1): 3.

Basu, S. and Haldar D.P. 2003. A comparative study on the prevalence of myxosporeans (Myxozoa: Bivalvulida) in pure and hybrid carps of West Bengal. Ecology Environment and Conservation, 9(2): 147-159.

Das BK, Mishra SS (2014) Diseases in Freshwater aquaculture, In: Training Manual on Model training course on Preventive health management practices in freshwater aquaculture. ICAR-Central Institute of Freshwater aquaculture, Bhubaneswar, Odisha, India.

Das, M. K., Halder D. P. and Mondal, S. K. 1989. Macro ecological studies on protozoan disease of carps in tropical intensive fish culture ponds in India. Environmental Ecology, 7(1):1-9.
Farhaduzzaman, A.M., Manjurul Alam, M. and Mosharrof Hossain, Afzal Hussain, M. Md. Habibur, Rahman, 2010. Prevalence of Parasites in the Indian Major Carp, Labeo rohita (Hamilton) in Rajshahi, Bangladesh, University of journal of zoology. Rajshahi. Univ. (28): 65-68.

Mishra SS, Das R, Dhiman M, Choudhary P, Debbarma J, et al., (2017) Present Status of Fish Disease Management in Freshwater Aquaculture in India: State-of-the-Art-Review. J. Aquac Fisheries 1: 003.

Narasimhamurti C.C. and Kalavati, C. 1984. Seasonal variation of themyxosporidian Hennegvya walairensis parasitic in the gills of the freshwater fish, Channapunctatus B1. Arch. Protistenk, 131: 351-356.

Sandeep P, Chamundeswari Devi B, Kumar KP (2016) Present status of Parasitic and Bacterial diseases in Fresh Water Fish Seed Farms in East Godavari District, Andhra Pradesh. International Journal of Applied and Pure Science and Agriculture 2: 117-121.

Vijaysundardeva, G., Gadadhar Dash, Kurva Raghu Ramudu, T.J. Abraham and Shyam, K.U. 2018. Prevalence of Parasitic Diseases of Indian Major Carps in Selected Districts of West Bengal, India. Int.J.Curr.Microbiol.App.Sci. $\quad 7(06)$ : 2784-2805.

Wisheiwski, W.L. 1958. Characterization of the parasite fauna of an Eutrophic lake. Actoparasitologica, 6: 1-64.

\section{How to cite this article:}

Yaswanth Kumar, J., S. Janardana Reddy and Suguna, T. 2020. Disease Prevalence of Indian Major Carps in Semi Intensive Culture System. Int.J.Curr.Microbiol.App.Sci. 9(04): 604-610. doi: https://doi.org/10.20546/ijcmas.2020.904.074 